\title{
Development of pollen grain in yellow passion-fruit (Passiflora edulis f. flavicarpa; Passifloraceae)
}

\author{
Margarete Magalhães de Souza and Telma Nair Santana Pereira
}

\begin{abstract}
To clarify events occurring during pollen grain formation in yellow passion-fruit (Passiflora edulis f. flavicarpa), floral buds were collected at different stages of development. After bracket, petal and sepal removal the anthers were fixed, dehydrated, embedded in paraffin wax, sectioned at $10 \mu \mathrm{m}$ and after differential dying with safranin $\mathrm{O}$ and fast green, mounted in Canada balsam and observed under optical microscope. Formation of the male gamete followed the normal pattern for angiosperms. Observation covered final sporogenic mass phase up to pollen grain formation; microsporangium tissue modifications were also observed. Microsporogenesis was characterized by sporogenic tissue differentiation in microsporic mother cells, followed by meiosis and resulting in tetrads. Microgametogenesis began with callose microspore release, subsequent mitosis, in addition to radial and tangential tapetum wall degradation, parietal layer compression nearer to the tapetum and endothecium widening, terminating in mature pollen grain formation.
\end{abstract}

\section{INTRODUCTION}

Yellow passion-fruit (Passiflora edulis Sims f. flavicarpa Deg.) belongs to the Passifloraceae family and is represented in Brazil by two genus: Dilkea and Passiflora. The Passiflora genus originated in tropical South America with its major center of geographical distribution in northcentral north of Brazil (Bruckner, 1994). Cultivated for its ornamental, medical and nutritive characteristics (Lopes, 1994), passion-fruit marketed in Brazil in 1996 amounted 30 thousand tons, more than $90 \%$ of which was domestically consumed (MMA, 1998).

Yellow passion-fruit is an allogamous plant mainly due to its floral morphology and self-incompatibility. Extremely colorful and aromatic, with abundant nectar, passion-fruit flowers virtually insure insect pollination. Such factor favors pollination by insects (Silva and São José, 1994; Hoffmann, 1997), specially since pollen grains are heavy and sticky.

Structurally, the passion-fruit flower's anther is generally made up of microsporangia developing when the anther begins to form. Normal development of the male gamete in dicotyledonous plants consists of two phases. In the first, microsporogenesis, sporogenic tissue differentiates into microspore mother cells, undergoes meiosis resulting in tetrads, a quartet of microspores maintained inside the callose until release. The phase extending from early-pollen into mature pollen grain formation is called microgametogenesis (Horner and Palmer, 1995). Genes operating from pre- to postmeiotic mitosis control formation of functional gametes and by acting together harmoniously, occasion the formation of four haploid cells (Pagliarini et al., 1997).
By correlating male cells and remaining tissues Horner and Palmer (1995) classified the anther development into 10 stages: 1 , sporogenic mass; 2 , meiocytes; 3 , dyad; 4, tetrads; 5 , early-microspore; 6 , mid-microspore; 7, late-microspore; 8 , early-pollen grain; 9 , mid-pollen grain, and 10, late-pollen grain. The microgametophytes, full of storage, have two or three nuclei according to the species; the endothecium cell wall becomes thick and the anther begins to dehydrate, causing its opening and consequent release of pollen grains. According to Pacini and Franchi (1993), pollen and spore dispersion always involves tapetum dispersion.

Tapetum cells play an important physiological role, since all nutrients reaching the sporogenic cells pass through them (Maheshwari, 1950). The phases undergone by the tapetum cells are associated with anther development. In the interval between dyad and microspore stage, the tapetum cells experience dramatic changes such as partial digestion of the internal tangential wall, as well as digestion of radial wall internal portions. In the interval separating early- and mid-microspore stages, the tapetum seems to secrete a material like that of the pollen wall into the space surrounding the microspores. Whether glandular or secretory, the tapetum remains peripheral, but if amoeboid, it migrates to the locus involving the microspores. In the final microspore phase, the tapetal cells present signs of exhaustion and can secrete materials such as pollenkitt, or trifine, around or over the pollen walls and furthermore, be able to identify substances. In the young pollen grain stage, the tapetum cells seem to be degenerating, although this stage rightly precedes their end. If this happens prematurely, abortion of male cells can occur (Horner and Palmer, 1995).

Laboratório de Melhoramento Genético Vegetal, Centro de Ciências e Tecnologias Agropecuárias, 
Finally, tapetum cells are almost entirely absorbed when secretor type microspores, common in angiosperms, start separating from each other (Maheshwari, 1950).

This research aimed to distinguish the most finely identifiable stages in the process of male gamete formation.

\section{MATERIAL AND METHODS}

Flower buds at different stages of development were randomly collected, 5 buds per plant, from ten plants taken from the field. The anthers were fixed separately in a 3\% glutaraldehyde - $4 \%$ paraformaldehyde solution in sodium cacodilate buffer solution $(0.1 \mathrm{M}, \mathrm{pH} 7.2)$, at room temperature $\left(22^{\circ} \mathrm{C}\right)$, after being submitted to negative pressure for one hour. Fixation was followed by three washes in buffer solution. After washing, these buds were dehydrated through a graded ethanol - xylene series, infiltrated with paraffin (Histosec). Longitudinal sections were cut on a rotary microtome at $10 \mu \mathrm{m}$, stained with Safranin, counterstained with fast green (Berlyn and Miksche, 1976), and mounted permanently on slides with a cover slip. Microscopic observations and photomicrographs were made using an optical microscope.

\section{RESULTS}

The observations were initiated in anthers $2.5 \mathrm{~mm}$ in length. At the start of meiotic division, the meiocytes were surrounded by a thin callose wall. The meiocytes presented centralized nuclei (Figure 1A). Below the endothecium cells, four medium or parietal layers were observed, whereas cells from layers closest to the endothecium were approximately three-fold in width compared to the remainder. Tapetum cells presented dense binucleated cytoplasm, although some remained mononucleated. At meiosis I termination, the tapetum cells, while maintaining rectangular format, increased following anther growth; the cytoplasms continued dense and the callose thickened. The meiocytes increased in width, although cell number was observed to be decreasing inside the microsporangium whereupon dyad formation (Figure 1B) immediately ensued.

The second meiotic division was not synchronized. Preceding tetrad formation, small spaces between radial walls and rounding of the edges of tapetal cell internal tangential walls were observed. At second meiotic division conclusion it was observed four haploid nuclei in a tetrahedral configuration inside a callose coating (Figure 1C). However, in the same microsporangium cells undergoing telophase I and II were perceived. Simultaneous cytokinesis only occurs at second meiotic division termination. Separation is synchronized, with four-nucleated cell division into four haploid microspores. While inside tetrads, the microspores presented a fine lightly ornamented exine. The early-microspores were released from the callose with oval format. Tapetal cell radial walls, in wearing out, created small spaces between them. Tapetal cell shape changed from rectangular to slightly triangular due to wall erosion, until edges appeared rounded.

During microspore development, the variously sized endothecium cells increased in length and width. Parietal cell layers nearest to tapetum underwent gradual flattening until total disappearance. Erosion of tapetal cells by rounding of tangential wall edges also occurred gradually, until only their traces remained. During microgametogenesis, the initially ovally formatted microspores (Figure 1D) became round. The exine layer thickened and became very ornamented. A gelatinous substance, perhaps polenkitt, involved all microspores.

The fully matured microspore presented a large vacuole and haploid nucleus (Figure 1E). Mitotic division produced a pollen grain with two nuclei: vegetative and generative (Figure 1F). The tapetum cell vestigial layer surrounding the pollen grains apparently degenerated inside the microsporangium. The endothecium reached maximum size and the parietal layer cells vanished.

\section{DISCUSSION}

Pollen grain development in Passiflora edulis f. flavicarpa followed the usual angiosperm pattern, that is, the sporogenic tissue underwent meiotic divisions, forming microspores that, following mitotic division, resulted in pollen grains. The first meiotic division occurred synchronously in yellow passion-fruit. McCormick (1993) mentions that in many plants such meiotic division occurs inside the anther, probably due to cytoplasmic connections (plasmodesmata) visible in the microspore mother cells. According to Frankel (1973), such interdependency between meiocytes, and between them and tapetal cells, is evident in prophase beginning. At its end, cytoplasmic connections between tapetum and meiocytes are interrupted by callose deposition in the meiocytes. But protoplasmic filaments between the meiocytes maintain a common cytoplasmic matrix, imposing synchronism in nucleus behavior. Such cytoplasmic connections were described in studies involving Zea Mays (Caetano-Pereira and Pagliarini, 1996), Brassica campestris (Souza and Pagliarini, 1995) and Centella asiatica (Consolaro and Pagliarini, 1995a,b). The nuclear independence of meiocytes, causing possible lack of synchrony in the second meiotic division, generally occurs in anaphase II (Frankel, 1973).

In Passiflora edulis f. flavicarpa, cytokinesis is simultaneous, though not occurring until termination of the second meiotic division. In the same microsporangium, meiocytes in telophase I and II were observed, indicating nuclear independence present at meiosis II beginning. Simultaneous occurrence of all phases of meiosis II in the same flower bud probably occurred due to meiocyte position inside the microsporangium because nutritional benefits to meiocytes nearest to tapetal cells probably lead to quicker meiotic division, according to Maheshwari (1950). 

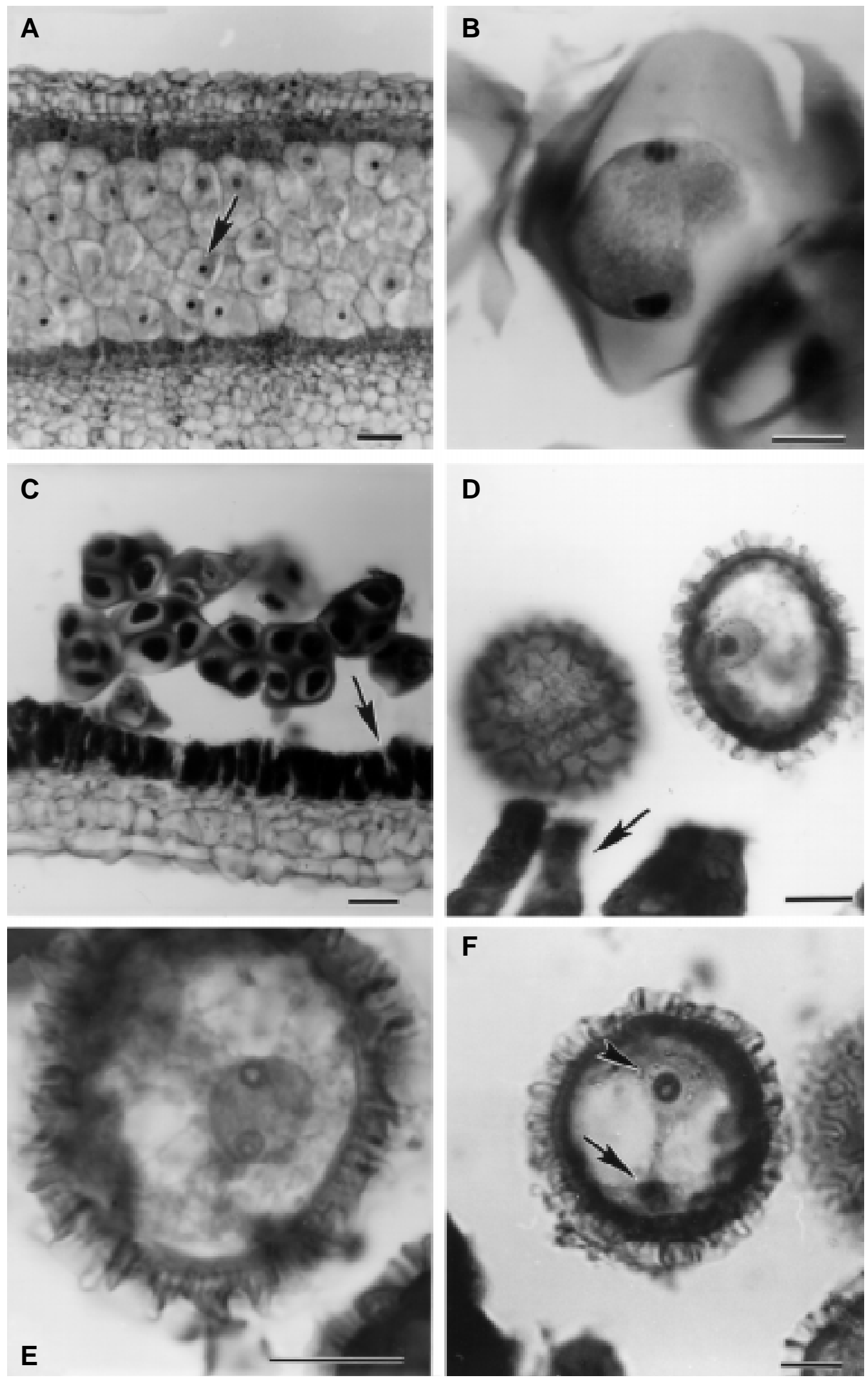

Figure 1 - Development of pollen grain in Passiflora edulis f. flavicarpa Deg. A, Early development of pollen grain - microsporangium with meiocytes presenting centralized nucleus (arrow); $\mathbf{B}$, microspore mother cell - meiocyte in telophase I; $\mathbf{C}$, microsporangium with quartet of cells in tetrahedral arrangement ending in callose - tetrads; tapetal cells presenting radial and tangential wall erosion (arrow); $\mathbf{D}$, microspore with oval aspect and nucleus no longer centralized; tapetal cells presenting accentuated erosion on radial walls (arrow); $\mathbf{E}$, late-microspore with nucleus in first telophase of first mitotic division; $\mathbf{F}$, noticeably young pollen grain presenting generative nucleus or spermatic (arrowhead) and vegetative nucleus (arrow) after first mitotic division. Scale bar $=25 \mu \mathrm{m}$. 
In the microspore stage, synchronism is reestablished, and according to Ciampolini et al. (1993), when many pollen grains are present in the microsporangium competition develops for food, probably leading to microspores locomotion, facilitating diffusion of substance secreted from the tapetum cells, which could explain reestablishment of synchrony in pollen grain formation. Among the meiocytes, locomotion is hindered due to the callose, to the probable existence of cytoplasmic bridge remains, and to the great proximity among the meiocytes.

In yellow passion-fruit, the beginning of erosion in tapetal cell tangential and radial walls was observed in the tetrad stage. In soybeans, according to Palmer et al. (1992), tapetal cell internal radial and tangential walls partially dissolve preceding the tetrad stage. In Cucurbita pepo, at second meiotic division termination, tapetal cells presented a thicker internal tangential wall, due to accumulation of polysaccharides later reabsorbed during microspore development, only beginning to decrease in the initial tetrad stage (Ciampolini et al., 1993).

According to the species, tapetal cell nucleus number varies, which could be related to metabolic activity of these cells. In Glycine max (Palmer et al., 1992) and Cucurbita pepo (Ciampolini et al., 1993) tapetal cells remained mononucleated during the entire anther development. Maheshwari (1950) reports that in Oenothera rubricalyx, tapetum cells are mononucleated at first, later becoming binucleated; the genus Lathraea presents mononucleated cells on one side of microsporangium and binucleated cells on adjacent side of connective tissue; in Lactuca sativa tapetum cells on one side of the microsporangium can be polynucleated and binucleated on the other. These differences possibly occur due to variation in amount of nutritive material passing through the cell. Carvalheira and Guerra (1997) studied tapetum cells in Passiflora cincinnata, $P$. caerulea, $P$. foetida, $P$. misera, $P$. racemosa and $P$. suberosa and observed binucleated polyploid cells, with partially fused nucleus which, according to the authors, suggests abnormality in chromosome separation. In yellow passionfruit, right in the beginning of microsporogenesis, some tapetum cells were mononucleated and others binucleated. At the end of meiosis II most cells were bi- or polynucleated, not previously having had a determined localization in the microsporangium.

According to Ciampolini et al. (1993), after total loss of its walls in the final stage of tetrad, tapetum secretion cells can begin their main activity: formation and transport of substances passing through them until reaching the microsporangium. In yellow passion-fruit, mature microspores were involved by a gelatinous substance, probably pollenkitt; in insect-pollinated species, tapetal cells degenerated and cytoplasmic material remains consisting mainly of pollenkitt, which is deposited on pollen grain surface before anther opening.

The subepidermal cell layer is the endothecium, whose cells reach maximum development elongating radially when pollen grains mature, ready for release from the anther (Maheshwari, 1950). In yellow passion-fruit, the endothecium already extends in a radial manner during dyad phase, apparently maintaining the same size until final tetrad stage, but during the final phase of pollen grain it reaches approximately four times the length of the epidermis, contrary to the tapetum cells, vestigial during this phase.

\section{ACKNOWLEDGMENTS}

The authors are grateful to Dr. Ricardo Pereira Louro (UFRJ), Dr. Ney Sussumu Sakiyama (UFV) and Dra. Magali Hoffmann (UENF) for critical reading of the manuscript and to FENORTE (Fundação Estadual do Norte Fluminense) for financial support of this research.

\section{RESUMO}

Visando elucidar os processos que ocorrem durante a formação dos grãos de pólen em maracujá amarelo (Passiflora edulis f. flavicarpa), foram coletados botões em diferentes estádios de desenvolvimento. As anteras foram desidratadas, embebidas em parafina, cortadas a $10 \mu \mathrm{m}$ e, após a coloração diferencial com safranina e verde rápido, montadas em bálsamo do Canadá e observadas sob microscópio óptico. A formação do gameta masculino seguiu padrão normal para angiospermas. A observação foi iniciada na fase final de massa esporogênica indo até a formação do grão de pólen, tendo sido também observadas as modificações ocorridas nos tecidos do microsporângio. A microsporogênese foi caracterizada pela diferenciação do tecido esporogênico em célulasmãe de micrósporos, passando por meiose e resultando em tétrades. A microgametogênese iniciou-se com a liberação dos micrósporos da calose, os quais passaram por mitose, além de degeneração das paredes radiais e tangenciais do tapete, compressão das camadas parietais mais próximas ao tapete e alargamento do endotécio, encerrando-se com a formação dos grãos de pólen maduros.

\section{REFERENCES}

Berlyn, G.P. and Miksche, J.P. (1976). Botanical Microtechnique and Cytochemistry. The Iowa State University Press, Ames, Iowa, pp. 326.

Bruckner, C.H. (1994). Auto-incompatibilidade em maracujazeiro. In: Maracujá: Produção e Mercado (São José, A.R., ed.). Universidade Estadual da Bahia, Bahia, pp. 6-18.

Caetano-Pereira, C.M. and Pagliarini, M.S. (1996). Citomixia em microsporócito de milho (Zea mays L.). Braz. J. Genet. 19 (Suppl.): 140.

Carvalheira, G. and Guerra, M. (1997). Organização da cromatina em células do tapete da antera em 15 espécies de angiospermas. Braz. J. Genet. 20 (Suppl.): 79.

Ciampolini, F., Nepi, M. and Pacini, E. (1993). Tapetum development in Cucurbita pepo (Cucurbitaceae). Plant Syst. Evol. 7 (Suppl.): 13-22.

Consolaro, M.E.L. and Pagliarini, M.S. (1995a). Correlação entre anormalidades meióticas, fertilidade do pólen e produção de sementes em Centella asiatica (L.) Urban (Umbelliferae). Rev. Bras. Genet. 18 (Suppl.): 429.

Consolaro, M.E.L. and Pagliarini, M.S. (1995b). Ocorrência de citomixia em Centella asiatica (L.) Urban (Umbelliferae). Rev. Bras. Genet. 18 (Suppl.): 428.

Frankel, R. (1973). Characterization of male sterility. In: Seminar of Agricultural Genetics for Latin America, Maracay, 1969. John Wiley \& Sons, New York, pp. 71- 83.

Hoffmann, M. (1997). Polinização do maracujá amarelo Passiflora edulis f. 
flavicarpa Deg. In: Maracujá: Temas Selecionados (1) (Manica, I., ed.). Cinco Continentes, Porto Alegre, pp. 58-70.

Horner, H.T. and Palmer, R.G. (1995). Mechanisms of genic male sterility. Crop Sci. 35: 1527-1535.

Lopes, S.C. (1994). Citogenética do maracujazeiro - Passiflora spp. In: Maracujá: Produção e Mercado (São José, A.R., ed.). Universidade Estadual da Bahia, Bahia pp. 19-23.

Maheshwari, P. (1950). An Introduction to the Embryology of Angiosperms. McGraw-Hill, New York, pp. 453.

McCormick, S. (1993). Male gametophyte development. Plant Cell 5: 12651275.

Ministério do Meio Ambiente, dos Recursos Hídricos e da Amazônia Legal (MMA), Secretaria de Recursos Hídricos, Departamento de Aproveitamento Hidroagrícola (1998). Frutiséries 4: Maracujá Amarelo. Brasília, pp. 2.
Pacini, E. and Franchi, G.G. (1993). Role of tapetum in pollen and spore dispersal. Plant. Syst. Evol. 7 (Suppl.): 1-11.

Pagliarini, M.S., Freitas, P.M., Carraro, L.R., Adamowski, E.V., Silva, N. and Batista, L.A.R. (1997). Citogenética de Paspalum III. Formação de gametas 2N. Braz. J. Genet. 20 (Suppl.): 86.

Palmer, R.G., Albertsen, M.C., Horner, H.T. and Skorupska, H. (1992). Male sterility in soybean and maize: developmental comparisons. Nucleus 35: 1-18.

Silva, A.C. and São José, A.R. (1994). Classificação botânica do maracujazeiro. In: Maracujá: Produção e Mercado (São José, A.R., ed.). Universidade Estadual da Universidade da Bahia, Bahia, pp. 1-5.

Souza, A.M. and Pagliarini, M.S. (1995). Ocorrência de citomixia em Brassica campestris (Brassicaceae). Rev. Bras. Genet. 18 (Suppl.): 411.

(Received August 19, 1999) 
